University of Nebraska - Lincoln

DigitalCommons@University of Nebraska - Lincoln

USDA National Wildlife Research Center - Staff Publications
U.S. Department of Agriculture: Animal and Plant Health Inspection Service

2019

\title{
Estimating economic impact of black bear damage to western conifers at a landscape scale
}

Jimmy D. Taylor

USDA APHIS Wildlife Services NWRC, jimmy.d.taylor@usda.gov

Kristina N. Kline

Oregon State University

Anita T. Morzillo

University of Connecticut

Follow this and additional works at: https://digitalcommons.unl.edu/icwdm_usdanwrc

Part of the Life Sciences Commons

Taylor, Jimmy D.; Kline, Kristina N.; and Morzillo, Anita T., "Estimating economic impact of black bear damage to western conifers at a landscape scale" (2019). USDA National Wildlife Research Center - Staff Publications. 2211.

https://digitalcommons.unl.edu/icwdm_usdanwrc/2211

This Article is brought to you for free and open access by the U.S. Department of Agriculture: Animal and Plant Health Inspection Service at DigitalCommons@University of Nebraska - Lincoln. It has been accepted for inclusion in USDA National Wildlife Research Center - Staff Publications by an authorized administrator of DigitalCommons@University of Nebraska - Lincoln. 


\title{
Estimating economic impact of black bear damage to western conifers at a landscape scale
}

\author{
Jimmy D. Taylor ${ }^{\mathrm{a}, *}$, Kristina N. Kline ${ }^{\mathrm{b}}$, Anita T. Morzillo ${ }^{\mathrm{c}}$ \\ a USDA APHIS, Wildlife Services, National Wildlife Research Center, 321 Richardson Hall, Corvallis, OR 97331, USA \\ ${ }^{\mathrm{b}}$ Department of Forest Ecosystems and Society, Oregon State University, 321 Richardson Hall, Corvallis, OR 97331, USA \\ ${ }^{\mathrm{c}}$ Department of Natural Resources and the Environment, University of Connecticut, 1376 Storrs Rd., Storrs, CT 06269, USA
}

\section{A R T I C L E I N F O}

\section{Keywords:}

Black bear

Douglas-fir

Economic impacts

Peeling

Pseudotsuga menziesii

Timber damage

Ursus americanus

\begin{abstract}
A B S T R A C T
Black bear (Ursus americanus) damage to trees in the Pacific Northwest is common, although volume and economic losses are unknown. Common measures to quantify bear damage to conifers at large scales rely solely on aerial estimates of red tree crowns (caused by complete girdling) and broad assumptions about stand characteristics. We surveyed 122 vulnerable stands in the Coast Range and western Cascades of Oregon using both aerial surveys and ground surveys. Then, we modeled 4 damage scenarios (Salvage; Total Loss; Root Disease; and Combined Damage) with the Forest Vegetation Simulator (FVS) growth and yield model and the Fuel Reduction Cost Simulator (FRCS). Damage polygons, digitized in real time from aerial surveys identifying red (dead or dying) tree crowns, overestimated bear damage by approximately 5 -fold due to misclassification with root disease, and failed to detect partially peeled trees that contributed to economic loss. Damage polygons assessed from the air generally did not include red crowns, and were a mean distance of $58.8 \mathrm{~m}$ (SE $=8.8$ ) from damage polygons' outer edges to the nearest red crown. We accounted for mortality and volume losses from partially girdled trees that did not show red crowns in our Salvage scenario, whereas we assumed that all bear-peeled trees resulted in complete loss in the Total Loss scenario. At the landscape scale, economic loss was $\leq 0.35 \%$ of net present value under both damage scenarios, while processing bear damage trees (Salvage) was the most efficacious option. At the landscape scale, our worst-case scenario (Total Loss) resulted in an estimated loss of $\$ 56 /$ ha to bear damage, 10 -fold less than a previously reported estimate of $\$ 585 /$ ha. Root disease was a more prevalent damage agent than bear damage but did not affect net present value at harvest. The majority (92\%) of bear damage observed in ground surveys was older ( $>2 \mathrm{yrs}$ ) and existed at a low frequency (1.5 bear damaged trees/ha) and severity across the landscape. Our results suggest that black bear damage is not uniformly distributed and that perceived impact varies with spatial scale. On-the-ground monitoring of the status of bear damage across the western Oregon landscape will identify hot spots of severe peeling and provide an understanding of these changes over time.
\end{abstract}

\section{Introduction}

Wildlife damage is an ongoing concern for forest resource management. Among vertebrate species, black bears (Ursus americanus) are perceived to have the greatest economic impact to young western conifers because bears usually damage the largest, most vigorously growing trees within the most productive stands (Kimball et al., 1998a; Schmidt and Gourley, 1992). Following winter dormancy, common food sources for black bears (e.g., Rubus spp., Vaccinium spp.) are scarce, requiring them to find additional sources of energy (Ziegltrum, 2004). In spring, black bears find this energy by peeling away bark to consume the sugar-rich phloem and cambial tissues (hereafter vascular tissues) of vigorously growing conifers (Radwan, 1969). In the Pacific Northwest, the most common conifer foraged is young Douglas-fir (Pseudotsuga menziesii), particularly within the 15-40 year age range (Flowers, 1987). Damage is typically concentrated at the base of trees where the quality of wood is greatest, and where the majority of the tree's wood volume is concentrated (Schmidt and Gourley, 1992). However, some black bears climb and peel trees where secondary metabolites are less concentrated (Kimball et al., 1998c), and bark is thinner and easier to peel (Schmidt and Gourley, 1992). Full girdling results in tree mortality, while partially girdled trees possess degraded wood quality and are more susceptible to disease, insect infestation (Kanaskie et al.,1990), and windfall (Witmer et al., 2000). Thus,

\footnotetext{
* Corresponding author.

E-mail address: jimmy.d.taylor@aphis.usda.gov (J.D. Taylor).
} 
impacts to timber stands from black bear damage can be substantial, especially since many stands are damaged by black bears for multiple years in a rotation (Kline et al., 2018). Based on field measurements, Kline et al. (2018) estimated that black bear damage at the stand scale resulted in a $4-46 \%$ loss of net present value in stands that were identified as having severe black bear damage. However, to our knowledge, there are no studies that have used field-based methods or growth and yield modeling to assess such economic losses at the landscape or regional scale (Taylor et al., 2014).

Currently, black bear damage in commercial timber stands is only assumed to result in substantial economic loss across scales. Historically, standard damage frequency estimates at the landscape scale have relied on damage detection through aerial surveys (Hartwell and Johnson, 1987). Trees that die as a result of bear damage typically show an observable change in foliar color from green to red by the following spring. Such red crowns can be detected remotely by air or from distant viewpoints on the ground. Red crowns are a potential index for extrapolating the total amount and economic impact of black bear damage at a specific period in time (Hartwell and Johnson, 1987).

In western Oregon, aerial surveys have been conducted annually by Oregon Department of Forestry (ODF) and the U.S. Forest Service (USFS) since 1987 to detect red (dead or dying) crowns and document tree mortality from black bears in western Oregon. Trained observers in fixed-wing aircraft digitize polygons in real-time to draw boundaries around red crowns (i.e., damage polygons). Boundaries vary in size and rules for number of red crowns per polygon are standardized among observers. These surveys are currently the only estimate of damage amounts over a large geographic area (Kanaskie et al., 2001), covering approximately 3.1 million ha each year (Flowers et al., 2014). However, aerial surveys for black bear damage focused on detecting red crowns are an annual estimate of trees completely girdled by black bears only the previous year, and do not estimate partial peeling or cumulative damage. Additionally, the aerial damage surveys have been ground verified twice since they began, revealing various weaknesses in their accuracy including misclassification with other mortality agents (Kanaskie et al., 1990, 2001).

To date, only 2 studies have estimated economic loss to black bear damage at broad scales (Nolte and Dykzeul, 2002; Taylor et al., 2014). Although informative, these estimates lacked stand assessments and were derived solely from aerial surveys of red crowns using broad assumptions of average tree age, economic value per tree, and tree density. Kline et al. (2018) was the first known study to integrate forest growth and yield models, harvest simulations, and present value models in quantifying black bear damage. They also improved estimates by including stand assessments and accounting for trees that were damaged but not killed (Kline et al., 2018). In this study, our objective was to improve our knowledge of the potential impacts of black bear damage at large scales by expanding upon this conceptual framework and methodology (Kline et al., 2018). This study builds upon such previous research (Nolte and Dykzeul, 2002, Taylor et al., 2014) by: (1) evaluating the accuracy of the black bear damage portion of the aerial forest health surveys for western Oregon, (2) accounting for volume loss and gain at the landscape scale, and (3) incorporating tools and techniques commonly used in forest valuation, such as growth and yield models, harvest simulators, and present value models into black bear damage assessments.

\section{Methods}

\subsection{Study area}

The study area included 122 intensively managed Douglas-fir stands on private land in the western Cascades and Coast Range of Oregon (Fig. 1). The Western Cascades ecoregion extends down-slope from the Cascade Mountains summit to the foothills of the Willamette, Umpqua, and Rogue valleys, and spans the entire length of the state of Oregon, from the Columbia River to the California border (ODFW, 2006). The mild maritime climate is characterized by cool, wet winters and hot, dry summers (Immell et al., 2013). Elevation ranges from sea level to $3500 \mathrm{~m}$. Average annual rainfall is $107-226 \mathrm{~cm}$ and average snowfall above $1220 \mathrm{~m}$ is $18-592 \mathrm{~cm}$ (ODFW, 2006). This ecoregion is almost entirely forested by conifers. Douglas-fir is the most common tree species below $1220 \mathrm{~m}$, often mixed with western hemlock (Tsuga heterophylla) as a co-dominant. At higher elevations, dominant tree species include Pacific silver fir (Abies amabilis), mountain hemlock (Tsuga mertensiana), or subalpine fir (Abies lasiocarpa). Other common conifers include western redcedar (Thuja plicata), grand fir (Abies grandis), and noble fir (Abies procera) (ODFW, 2006). Understory vegetation is comprised of vine maple (Acer circinatum), salal (Gaultheria shallon), rhododendron (Rhododendron macrophyllum), swordfern (Polystichum munitum), vanilla leaf (Achlys triphylla), Oregon oxalis (Oxalis oregano), and twin flower (Linnaea borealis, Immell et al., 2013).

The Coast Range ecoregion extends from the Pacific coast eastward through the coastal forest to the border of the Willamette Valley and Klamath Mountains. The area is comprised of rugged, mountainous terrain with steep slopes and deep river and creek drainages. Elevation ranges from sea level to $1250 \mathrm{~m}$. Climate is maritime with mild, wet winters and cool, dry summers (Cushman and McGarigal, 2003), and an average annual precipitation of $152-249 \mathrm{~cm}$ (ODFW, 2006). The forest overstory is dominated by Douglas-fir, western hemlock, and red alder (Alnus rubra). Western redcedar and bigleaf maple (Acer macrophyllum) are also common. Common understory vegetation include salmonberry (Rubus spectabilis), salal, vine maple, Oregon grape (Berberis spp.), huckleberry (Vaccinium sp.), and swordfern (Cushman and McGarigal, 2003).

Approximately $45 \%$ of western Oregon forestland is managed by federal agencies (OFRI, 2013). Approximately 30\% falls under large private industrial ownership, and $18 \%$ falls under small private ownership (OFRI, 2013). The remaining 7\% is managed by ODF and other nonfederal public entities (OFRI, 2013).

\subsection{Data collection}

We accessed black bear damage data from ODF and USFS aerial forest health surveys conducted in 2014-2015 (http://www.oregon. gov/ODF/ForestBenefits/Pages/ForestHealth.aspx). Trained observers recorded black bear damage from fixed-wing aircraft in early summer, as this is the optimal time to detect changes in foliar color among injured western conifers (Flowers et al., 2014). Flights followed a grid pattern $300-500 \mathrm{~m}$ above the ground with flight lines $6.5 \mathrm{~km}$ apart (Flowers et al., 2014). Observers recorded damaged areas by drawing curvilinear polygons on a digital sketch mapping system (Flowers et al., 2014). The resulting polygons designated approximate damage boundaries, and were coded with suspected damage agent and an estimated of number of trees affected. Areas of mature $(>30 \mathrm{~cm} \mathrm{dbh})$ Douglas-fir with red crowns in tight groups were coded as Douglas-fir beetle mortality, while all other red crowns were coded as bear damage unless an obvious alternative cause was evident (Kanaskie et al., 2001).

We obtained stand-scale spatial and relational data from cooperating forest landowners, and integrated those data with aerial survey data of black bear damage for 2014-2015 in a geographic information system (GIS). We randomly selected 35 stands in the western Cascades and 35 stands in the Coast Range (70 stands each year for 2 years; 140 stands total) that overlapped with a surveyed black bear damage polygon and were within the most common age range of vulnerability for black bear damage (11-34 years). After removing 8 stands because of access issues, and 10 aerial images that contained no red crowns to verify on the ground, 122 of the 140 sample stands were surveyed.

Sampling to assess wildlife damage influences extrapolation of damage estimates to the larger area (Engeman, 2002). In order to maximize the efficiency of establishing the ratio of actual black bear peeling 


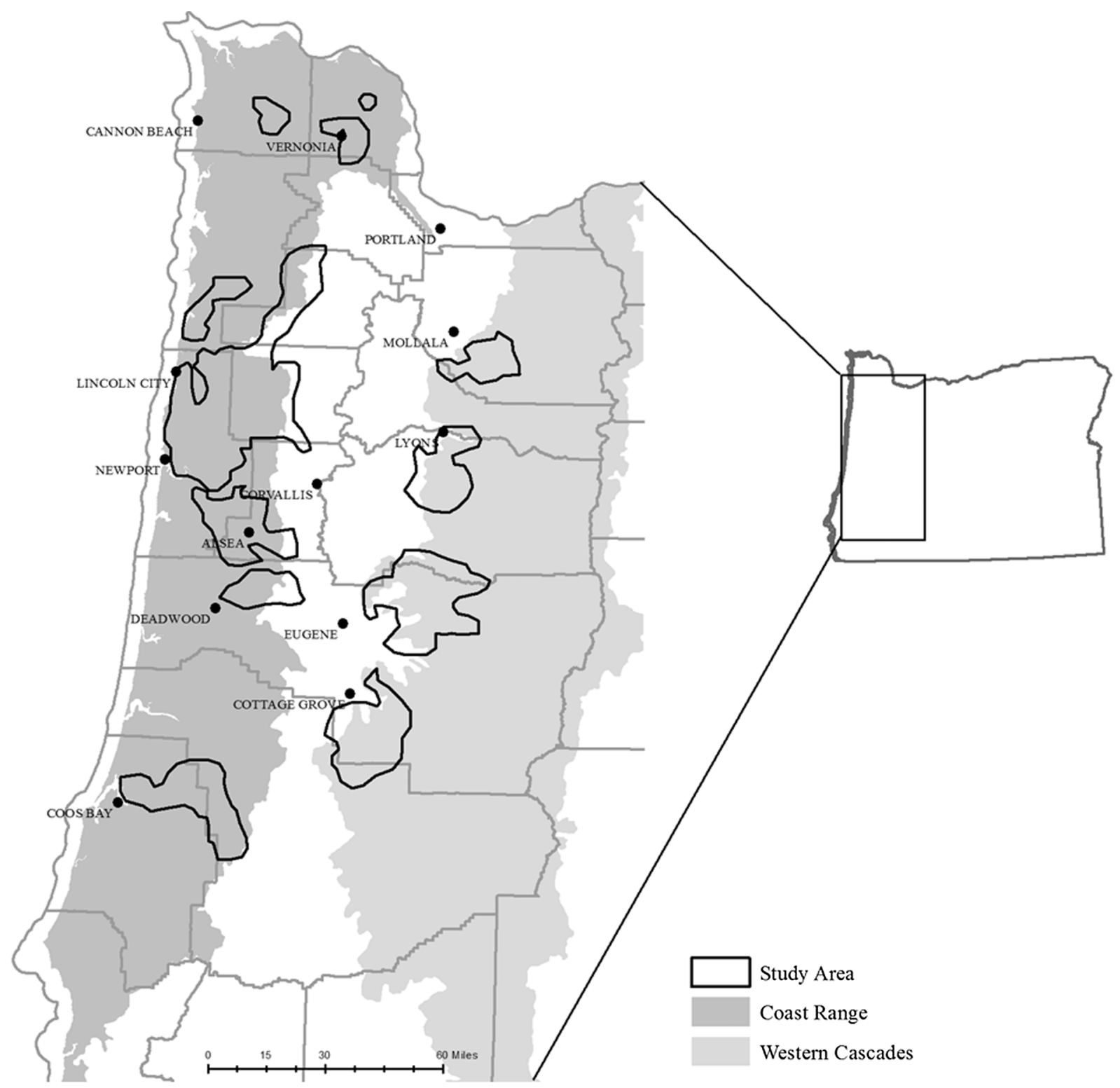

Fig. 1. Extent of study area in the Western Cascades and Coast Range of Oregon, USA.

frequency (i.e., partial and full girdling) to frequency of red crowns (i.e., full girdling causing mortality) we intensively sampled 0.04 ha circular plots within stands that contained red crowns. To obtain precise and accurate estimates of red crown locations, we acquired highresolution, geo-referenced aerial images of sample stands each year (2014-2015) just prior to ground sampling. A single plot was positioned around the largest group of red crowns within each stand's boundary, and within, or as close as possible to, a black bear damage polygon designated from aerial surveys.

Plots were systematically surveyed between July and October 2014-2015 to quantify damaged and undamaged trees. Two observers walked rows of trees back and forth across each plot while visually scanning trees from base to top for damage. One observer scanned one side of the row of trees, while the other observer scanned the opposite side. Data recorded for trees identified as black bear-damaged included tree species, severity of damage (percent of circumference peeled), age of damage, and crown condition (red, green, no needles). Age of peeling damage was determined using a pulaski to peel back bark surrounding the damaged area and count layers of new growth since damage. Trees damaged by root diseases were identified using a pulaski to expose roots and peel back bark. Damage from other agents and unknown sources also were recorded. Field staff were trained to identify signs of insect damage and species-specific signs of root diseases by an experienced forest pathologist (Alan Kanaskie, Oregon Department of Forestry, personal communication).

\subsection{Annual forest health survey validation}

To validate the accuracy of the black bear damage portion of the ODF and USFS annual forest health surveys, we compared estimates of on-the-ground damage frequency (black bear-damaged trees/ha) with aerial survey estimates of damage frequency using a chi-square test of accuracy (Freese, 1960). We evaluated only those plots that fell within a black bear damage polygon designated from the aerial survey. Analysis was completed using the statistical package R ( $R$ Development Core Team, 2010).

We measured the distance between polygons and the nearest red crowns on aerial imagery in GIS to assess the accuracy of the location of aerial survey polygons. Differences were reported using descriptive statistics. This assessment indicated how efficient the aerial survey was at designating polygons around true locations of red crowns. However, it did not indicate efficiency of the aerial survey at detecting true black 
bear damage locations, which would have required sampling a much greater proportion of each stand in order to verify all red crowns both inside and outside of black bear damage polygons.

\subsection{Landscape-scale damage estimation}

We created a stand-by-stand method to expand plot-scale frequency and severity data across the landscape, referred to as red crown-todamage ratios. First, we used field survey data to calculate a ratio of the number of black bear-damaged (both killed and wounded) trees and root disease-killed trees per observed red crown in each plot. Then, we calculated the mean of this ratio across all stands. We also calculated separate ratios for the number of trees peeled at severities of $100 \%$, $5-50 \%$ and $55-95 \%$ of their circumference per red crown.

To estimate stand-by-stand damage amounts, we used high-resolution aerial imagery to count the number of red crowns present within each stand. The alpha band in GIS was used to create a transparency mask on the images, which allowed red colors to contrast more intensely against the rest of the image and enhance the ability to count red crowns in each image. The number of red crowns identified in each stand was then multiplied by red crown-to-damage ratios to obtain a total estimate of black bear damaged trees (wounded and killed) and root diseased trees in each stand across the landscape. Using a paired $t$ test, we evaluated observer bias in detection of red crowns with a group of 7 trained photo observers who counted red crowns among a subsample of images.

\subsection{Landscape model construction}

Two models were needed to estimate harvestable timber volume and value from our estimates of damage frequency and severity across the landscape. We followed the methods of Kline et al. (2018) to apply a growth and yield model with a present stand value model after accounting for harvesting costs. Outputs of the growth and yield model became inputs for the present stand value model (Fig. 2). For a more detailed description of model inputs see Kline et al. (2018).

\subsubsection{Black bear damage impacts to forest stands}

We used the Forest Vegetation Simulator (FVS) growth model (Avery and Burkhart, 1983; Dixon, 2002) to estimate standing timber volume and simulate black bear damage impacts over time. We used the Pacific Northwest Coast (PN) variant for Coast Range sites, and the West Cascades (WC) variant for western Cascades sites (USDA, 2014). FVS inputs included both stand-scale information (Fig. 2b) and treescale information (Fig. 2a; dbh, height, and ratio of live crown height to height of tree, or crown ratio) in the form of "tree lists". To build tree lists for growth simulation, we used tree-scale data from 2 previous studies in the western Cascades and Coast Range of Oregon (Maguire et al., 2011), and which covered the same general area as our study area. We selected tree-scale data for which age, trees/ha, basal area, and quartile mean diameter were similar to our sample stands. We used an average harvest age of $45-50$ years for all projections.

\subsubsection{Economic losses to bear damage}

A present stand value model was used to translate volume losses into economic losses. Present value estimates require knowledge of volume at harvest (obtained from growth model outputs, Fig. 2c) and the value of logs delivered to the mill (pond value). These estimations also require knowledge of the logging and hauling costs that are subtracted from the value of logs delivered to the mill. We used the Fuel Reduction Cost Simulator (FRCS; Fig. 2d), FRCS-West variant (Fight et al., 2006) to estimate logging and hauling costs associated with each stand at harvest.

Data inputs included average yarding distance from the stand to a roadside landing, stand area, stand slope, elevation, harvesting system used, number of large trees/ha, and mean volume/large tree. Large trees/ha and mean volume/large tree were derived from growth model output tables (Fig. 2c) by dividing total volume/ha by trees/ha. We used an average yarding distance of $180 \mathrm{~m}$ for all stands. Slope values were derived from digital elevation model layers in GIS using the Spatial Analyst Slope Tool.

We used the special "Billion-Ton" processing rules (Dykstra, 2010) in FRCS, which designated a harvesting method based on the slope and volume/ha of each stand. For slopes was $\leq 40 \%$, two alternatives of a ground-based logging system were considered: either mechanical

Growth Model Inputs

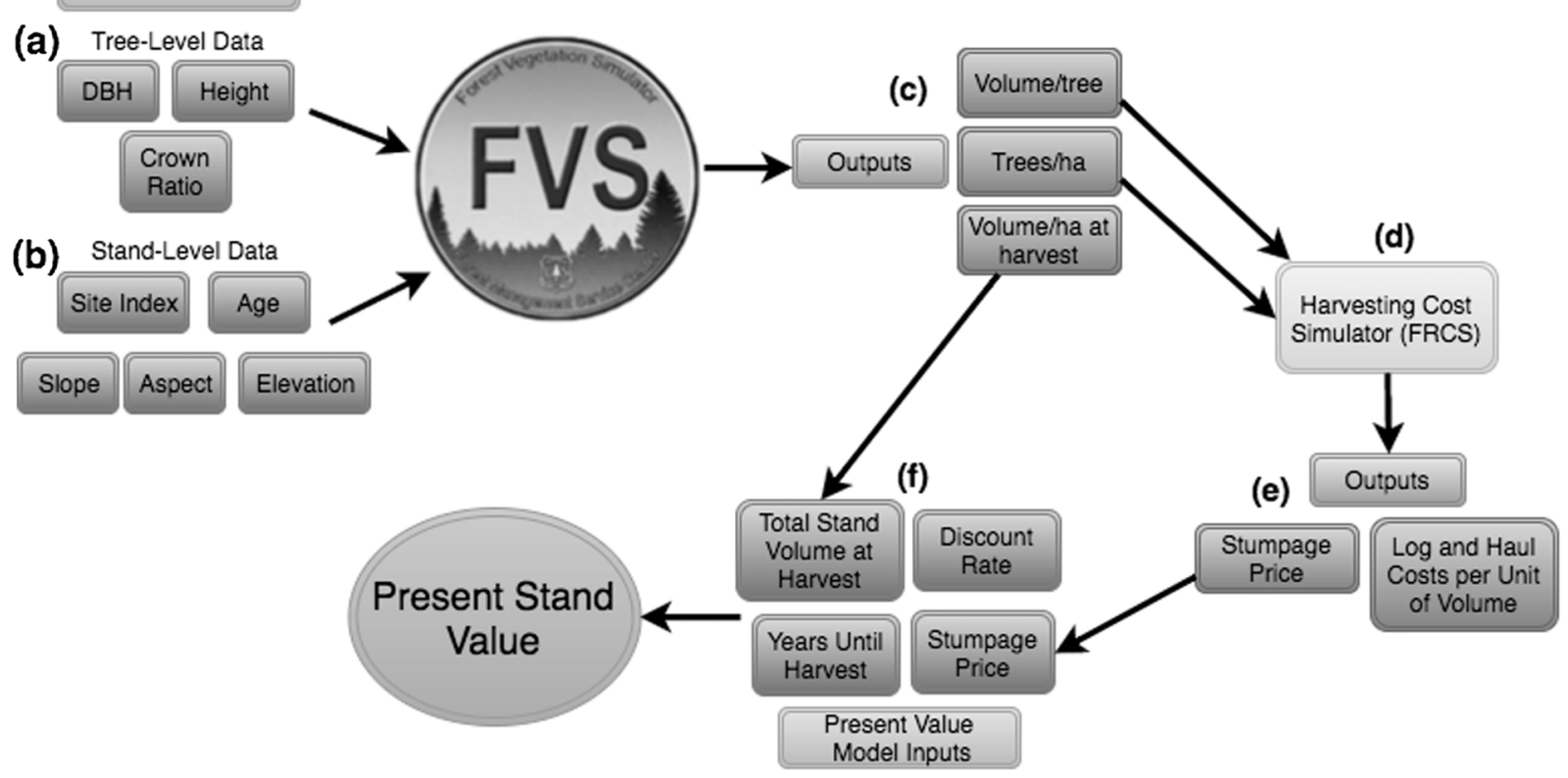

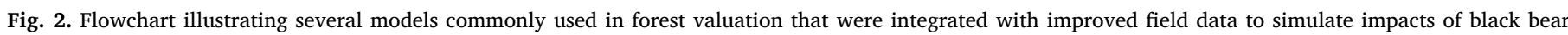
damage to private timberlands.

Adapted from Kline et al. (2018). 
whole-tree harvesting with feller-bunchers and skidders used to transport bunches, or manual whole-tree harvesting with chainsaws and skidders used to transport whole trees (Dykstra, 2010; Fight et al., 2006). FRCS calculates both alternatives and selects the lower-cost alternative (Dykstra, 2010). For slopes $>40 \%$, the simulator used manual felling and cable yarding as the harvesting system (Dykstra, 2010). The simulations harvested stands as clear-cuts and loading costs also were included.

Present stand value was estimated using the following Land Expectation Value (LEV) model (Fig. 2f):

$\mathrm{PV}=\frac{\mathrm{Vh} * \mathrm{SP}}{(1+i)^{y}}$

where $\mathrm{PV}=$ the present value of the stand in dollars (US), $\mathrm{Vh}=$ the total volume of the stand at the harvest age, SP = stumpage price or pond value (i.e., log value) minus logging and hauling costs, $i=$ the discount interest rate, and $y=$ the projected number of years from present to harvest age. We completed a series of simulations in the growth model using 10 stands that encompassed the full range of tree densities present across all stands to determine an average log value per thousand board feet (MBF). The output from these simulations was used to calculate an average distribution of volumes by log grade at harvest across all stands (Table 1). Then, we calculated a weighted mean log value per MBF based on this distribution and applied it in the present value calculation to all stands. Stand volume was distributed among 6 log grades: special mill, \#2 sawmill, \#3 sawmill, \#4 sawmill, chip-andsaw, and pulp logs. The most current market value for each grade was used in the calculation of weighted mean price per Douglas-fir MBF. We used a discount interest rate of $5 \%$, based on the most common interest rates of 4-6\% used in such calculations (Darius Adams, Oregon State University, personal communication). For each of the following model scenarios, the present values of all 122 stands were added together for a total present value across the landscape.

\subsubsection{Loss of timber volume from bear damage}

We developed 2 scenarios to explore estimated loss in timber volume due to black bear damage (Kline et al., 2018). Each scenario reflects a different landowner perception of black bear damage impacts. Because there is no application in FVS that accounts for loss of trees to wildlife damage, we simulated tree loss by conducting thinning operations in FVS to remove damaged trees. Thinnings are applied uniformly in FVS, and although bear damage often appears randomly as single trees or in small aggregates, we assume gains and losses of volume were captured using this technique. The first scenario (Salvage) removed all black bear damaged trees that retained harvestable volume. Loss in individual tree volume varied and was based on the results of previous research (Connie Harrington, USFS, Unpublished data; Lowell et al., 2010; Pierson, 1966), as described in Kline et al. (2018). For the Salvage scenario, we assumed that a percentage of black bearwounded trees would die, conditional on the percentage of circumference peeled (severity of damage). For trees that survived, a

\section{Table 1}

Average distribution of volume by different log grades at harvest, and weighted mean $\log$ value per Douglas-fir MBF used in present value calculations.

\begin{tabular}{llll}
\hline Log grade & $\begin{array}{l}\text { Log value/ } \\
\text { MBF }\end{array}$ & $\begin{array}{l}\text { Avg \% of total } \\
\text { volume }\end{array}$ & $\begin{array}{l}\text { Weighted mean value/ } \\
\text { MBF }\end{array}$ \\
\hline chip-and-saw & $\$ 187$ & 7 & $\$ 545$ \\
special mill & $\$ 700$ & 10 & \\
pulp logs & $\$ 107$ & 2 & \\
$\# 2$ sawmill & $\$ 605$ & 13 & \\
$\# 3$ sawmill & $\$ 550$ & 45 & \\
$\# 4$ sawmill & $\$ 525$ & 22 &
\end{tabular}

percentage of volume was assumed to be lost, also conditional on the severity of damage.

For the Salvage scenario, 2 thinning treatments were implemented in the growth model- an initial thinning where all bear-killed trees were removed immediately, followed later by removal of a proportion of the remaining wounded trees after growing the stands to harvest age. Our intent for the second thinning application was to simulate the percentages of black bear-damaged trees that were predicted to die over the course of the simulation. As a final step of volume estimation, we removed a percentage of cull volume from surviving wounded trees conditional on damage severity.

The second scenario (Total Loss) was based on observations made during the study in which cooperating landowners said they do not process bear-damaged trees, regardless of severity. In the Total Loss scenario, we assumed that all black bear damage resulted in a complete loss of the damaged tree's volume, regardless of whether the tree was wounded or killed. We also assumed that the costs required to salvage a black bear-damaged tree at harvest offset any profit that would be made from selling the tree, resulting in zero net revenue.

To simulate the Total Loss scenario in the growth model, we implemented 2 thinning treatments. We first immediately removed all trees that had been killed by black bears at the year of simulation initiation. Stands were then grown to harvest age and the remaining black bear-wounded trees were thinned from the stand. We chose to remove the wounded trees after the stand was projected, because in most cases, wounded trees are left to keep growing until harvest. It is at harvest when those trees become a complete loss. We used summary table outputs from FVS to calculate volume/ha and total standing volume for each stand. We then input volume information into the FRCS simulation, and computed present stand values.

Two additional scenarios were included to account for economic losses as a result of other observed damage agents. The third scenario (Root Disease) included volume losses from trees killed by root disease. We implemented a single thinning treatment to simulate the Root Disease scenario in the growth model. We immediately removed all root disease-killed trees and then projected to harvest age. This thinning was implemented as a reduction in trees/ha, and trees removed represented the full dbh range.

The fourth scenario (Combined Damage) included the combined volume losses from both trees killed by root disease and trees killed and/or damaged by bears. We implemented 3 thinning treatments to simulate the Combined Damage scenario in the growth model. We first removed all root disease-killed trees and all bear-killed trees at the start of the simulation. Then, we projected to harvest age and then thinned out the remaining bear-wounded trees. Removal of root disease trees was conducted across the full $\mathrm{dbh}$ range, while removal of black beardamaged trees was restricted to those of larger dbh in each stand.

Because we were interested in the amount of volume lost to damage, we developed an Undamaged scenario for stands to serve as a comparison of all other scenarios. We projected stands to harvest age in the growth model assuming complete lack of damage, and calculated volume at harvest. For all models, we used summary table outputs from FVS to calculate volume/ha and total standing volume for each stand. We then input volume information into the FRCS simulation, and computed present stand values.

In all models, we assumed bare land value for each stand was not affected by black bear damage; i.e., land containing damaged stands today is not likely to continue in perpetuity. Due to this assumption, our present stand value calculations are ratios of the timber values at the end of the current rotation and do not consider bare land values. From an economic standpoint, it would only be necessary to include bare land values if we suspected that some stands are inherently predisposed to repeated black bear damage in perpetuity. 
Table 2

Estimated economic losses due to bear damage across western Oregon under 2 damage scenarios, at multiple spatial scales.

\begin{tabular}{|c|c|c|c|c|}
\hline Area of impact & $\mathrm{Ha}$ & Undamaged value & $\begin{array}{l}\text { Lost value -salvage } \\
\text { scenario }\end{array}$ & $\begin{array}{l}\text { Lost value -total } \\
\text { loss scenario }\end{array}$ \\
\hline Surveyed stands ${ }^{\mathrm{a}}$ & 3024 & $\$ 47,911,520$ & $\$ 0$ & $\$ 168,950$ \\
\hline All stands $11-34$ yo with bear damaged polygons $2014 / 2015^{\mathrm{b}}$ & 36,236 & $\$ 574,114,487$ & $\$ 0-\$ 534,004^{\mathrm{c}}$ & $\$ 2,029,216$ \\
\hline
\end{tabular}

a Loss estimates reported for the 122 surveyed sample stands.

b Loss estimates reported for all stands within our study area aged 11-34 that overlapped with a bear damage polygon designated from the aerial surveys in 2014 and 2015 .

c Upper range assumes a worst-case based on a 1:4 loss between scenarios found at the stand scale in severely damaged stands (see Kline et al., 2018).

\section{Results}

\subsection{Validation of aerial forest health surveys}

Aerial survey estimates of black bear damage were less accurate than our observed estimates of damage on the ground $\left(X_{66}^{2}=119.20\right.$, $\mathrm{p}<0.01$ ). On average, aerial survey estimates of black bear damage frequency were 5.2 trees/ha greater $(S E=1.92)$ than our observed mean estimate of 1.5 black bear damaged trees/ha. Furthermore, black bear damage polygons from the aerial surveys often failed to contain red crowns, and polygon perimeters were a mean distance of $58.8 \mathrm{~m}$ $(\mathrm{SE}=8.8)$ to nearest true red crown locations.

\subsection{Black bear damage - plot scale}

Seventeen percent of plots surveyed $(n=122)$ contained black bear damage as the primary damage agent, while $82 \%$ of plots surveyed contained root disease as the primary damage agent. Four percent of plots contained damage by ungulate rubbing, and 1 plot $(<1 \%$ of all plots) contained substantial damage from girdling by mountain beaver (Aplodontia rufa). Nineteen percent of black bear damaged plots contained only trees wounded by black bears (i.e., no red crowns). The mean ratio of fully girdled trees to wounded trees across all plots was 1-2.5 (SE $=0.57$ ). We observed a total of 324 red crowns across all plots, $15 \%$ of which were the result of black bear damage, and $85 \%$ of which were the result of root disease. The margin of error in detection ability of our trained photo interpreters was \pm 2.1 red crowns per image (95\% confidence interval), and estimates did not differ among observers $\left(t_{7}=2.26, p=0.06\right)$. For every red crown observed in our images, there were on average 1.67 black bear damaged trees $(\mathrm{SE}=0.34 ; 1.09$ killed, 0.58 wounded) and 4.64 root diseased trees $(\mathrm{SE}=0.36)$. This was our red crown-to-damage ratio. We observed a total of 478 black bear damaged trees across all plots, of which 170 were killed. Of the 170 black bear killed trees, $71 \%$ were dead with no needles, while $29 \%$ were dead with red crowns. Sixteen percent of black bear damaged trees had climb-and-peel damage while the majority had basal peeling.

Black bear-killed trees with no needles were 2.5 times more abundant than black bear-killed trees with red crowns. Two percent of black bear-damaged trees had fresh damage (occurred during the year of observation), while $6 \%$ of black bear-damaged trees had damage that occurred the year prior to observation (i.e., red crowns). The majority of black bear damage observed (65\%) occurred $2-5$ years prior to observation, while $27 \%$ of black bear damage occurred over 5 years prior to observation. Only $1.5 \%$ of individual black bear-damaged trees experienced damage in multiple years.

\subsection{Black bear damage - stand scale}

Extrapolated to the stand scale, we observed a mean of 1.5 black bear-damaged trees/ha $(\mathrm{SE}=0.05)$ and 4 trees with root disease/ha $(\mathrm{SE}=0.25)$. For black bear damage, the greatest amount of trees removed through thinning treatments in the growth model was 2.5 trees/ ha, while most stands lost $<2$ trees/ha. For root disease, the greatest amount of trees removed through thinning treatments in the growth model was 23 trees/ha, while the majority lost $2-5$ trees/ha.

\subsection{Landscape-scale volume and economic losses}

Estimated undamaged value for the 3024 ha sampled was $\$ 47.9$ million (Table 2). After extrapolating damage estimates to the stand scale, results of the Salvage scenario projected that the total number of black bear damaged trees in each stand were too few to apply to the growth and yield model. Less than 1 wounded tree/ha remained available for the second simulated thinning; thus, removing such a small percentage of volume became impractical. Therefore, the Salvage scenario was removed from further analysis, and we concluded that salvaging black bear damage trees at this scale resulted in no loss or gain. In the Total Loss scenario, $0.35 \%$ of the total volume across the 122 stands was lost to black bear damage, resulting in an economic loss of $\$ 168,950$ (Table 2). In the Root Disease scenario, there was no volume loss and no economic loss. In fact, stands had slightly greater volume $(0.05 \%$ greater $)$ and were worth slightly more $(+0.04 \%)$ at harvest. In the Combined Damage scenario (combined effects of both black bear damage and root disease), there was a loss in volume of $0.31 \%$ across all 122 stands. This translates to an economic loss across all surveyed stands of $\$ 148,855$, or $\$ 20,095$ less than economic losses from black bear damage alone.

According to our model estimates, a loss of 1.5 black bear damaged trees/ha equates to an average economic loss of $\$ 56 /$ ha when no black bear damaged wood was processed. If we assume this level of black bear damage is present across all 11-34yo stands within our study area that overlapped with black bear damage polygons from the 2014-2015 aerial surveys ( 36,236 ha valued at $\$ 574.1$ million undamaged), direct economic losses to black bear damage were estimated at $\$ 2.03$ million, or $0.35 \%$ of net present value. This estimate was based on our Total Loss scenario where all black bear damaged trees (wounded or killed) resulted in a complete loss in volume. We were unable to calculate the Salvage scenario losses in the growth model at the landscape scale because observed black bear damage was so sparse across our study area. Thus, we infer the lower range of economic impact at this scale also was $\$ 0$ (Table 2). Kline et al. (2018) concluded that the Total Loss scenario losses were on average 4 times greater than the Salvage scenario losses at the stand scale where black bear damage was considered high. If we assume the same proportion of loss in a worst-case context, our Salvage scenario estimate of economic loss would be $\$ 534,004$ (one-fourth of $\$ 2.03$ million or $0.09 \%$ net present value, Table 2).

\section{Discussion}

Black bear damage to trees in the Pacific Northwest was first reported in the early 1900s (Pierson, 1966) along with other sources of wildlife damage (Black and Lawrence, 1992). However, black bear peeling was not considered a problem for timber production until intensive forest management practices increased markedly in the 1940s (Pierson, 1966). Ecologically, damage to trees is a normal consequence 
when wildlife search for food and cover in forests (McDonald and Radosevich, 1992) and some may argue that accepting wildlife damage is a cost of doing business in the forest resources industry. Thus, accurate estimates of black bear damage on private timberlands are important when making management decisions for both black bears and timber resources. Nolte and Dykzeul (2002) estimated that 25,900 ha of western Oregon timberlands incurred $\$ 11.5 \mathrm{M}$ in loss to black bear damage. Adjusted for inflation, 2015 loss exceeded \$15.1 M or \$585/ ha. In comparison, our worst-case estimates of loss were $\$ 56 /$ ha. Our estimates of direct economic loss to black bear damage improve upon existing estimates (Nolte and Dykzeul, 2002; Taylor et al., 2014) by verifying the frequency and severity of damage on the ground, including the additional impacts of wounded trees not detectable from the air, and coupling growth and yield models with present value models. Tree lists used to input growth and yield models were improved by accounting for variation in trees within stands and estimating volume loss of damaged trees based on circumference peeled. While recent results of black bear damage at the stand scale revealed a range of volume and economic loss from 4 to $46 \%$ (Kline et al., 2018), our results estimated $\leq 0.35 \%$ loss at a landscape scale. In our scenarios and in Kline et al. (2018), loss depended on how landowners perceived the impacts of black bear damage on their lands and if they desired to remove black bear damaged trees from the harvest units. At both scales, salvaging black bear-damaged trees was more economically viable than not harvesting them. Although this study was limited to western Oregon, our conceptual framework is transferable to many other locations and forest types where black bear damage occurs.

Industrial private landowners invest annually in management to reduce black bear peeling, although actual costs were not available for this study. Previous reports of costs to reduce black bear damage in western Oregon (adjusted to 2015) range from $\$ 76-\$ 618 /$ ha (Nolte and Dykzeul, 2002; Ziegltrum, 2006). In western Washington, managers use hunting with hounds as a tool to remove individual black bears in stands with fresh peeling. They also use supplemental feeding as a nonlethal tool to reduce peeling (Ziegltrum, 2004, 2006). In western Oregon, managers use trapping to selectively remove black bears in areas with fresh peeling. Ziegltrum (2006) found the supplemental feeding program to be cost-effective; however, his study extrapolated one stand to a larger landscape and did not account for differences in loss between partially and completed girdled trees. For our study, we acknowledge that preventive measures with unknown costs were employed to reduce black bear damage, an improvement that could be made in future research.

While the economic impacts of black bear peeling can be direct and indirect (Taylor et al., 2014), in this study we focused our assessment on direct losses as a result of black bear damage. We did not assess indirect losses (how the economy responds to the loss of timber volume from black bear damage) because the levels of damage observed were minimal. At the landscape scale, the overall market system would act to offset any supply reductions through substitution from other owners and regions. Thus, the impacts measured at the overall market or regional scale would be minuscule (Darius Adams, Oregon State University, personal communication).

From our results, aerial forest health surveys are a useful tool for forest managers, but not as accurate and precise as ground surveys (Kanaskie et al., 1990, 2001). In areas where multiple agents create the same signature (i.e., red crowns), validation is required to reduce misclassification error. In 2000, Kanaskie et al. (2001) found that $63 \%$ of areas identified as black bear damage from the air were misclassified and contained root disease. Additionally, they found an average of 2 wounded trees for every fully girdled tree with a red crown (Kanaskie et al., 2001). Although severe black bear damage occurs within some private forest stands (Kline et al., 2018), we found the frequency of severely black bear damaged stands across northwestern Oregon was minimal. More so, we found that polygons digitized from aerial surveys generally did not contain red crowns; polygons often occurred within adjacent stands (mean distance of $58.8 \mathrm{~m}$ from outside edge of polygon to nearest true red crown locations). This resulted in damage polygons often occurring within harvest units, non-forested areas, or other stands not vulnerable to peeling. Thus, aerial estimates tend to under or overestimate volume and economic loss.

Also accounted for by our models was the presence of other mortality agents that were observed extensively across the landscape, such as root disease. We observed 3 different types of root disease within our study area: laminated root rot (Phellinus weirii), black stain (Leptographium wageneri), and Armillaria (Armillaria obscura). Surprisingly, root disease was present at a higher frequency than bear damage but it resulted in no economic loss when evaluated across 3024 ha. In fact, stand values at harvest slightly increased when we removed trees lost to root disease. This result could be because root diseased trees removed in the model were smaller than the black bear damaged trees removed. The removal of inferior trees allowed for increased resources for the larger residual trees, resulting in a greater volume at harvest. It is important to note that our analysis assumes no further mortality from root disease, which is not likely given the typical expansion of laminated root rot pockets.

Our study was preceded by 2 other efforts to evaluate forest health surveys in Oregon (Kanaskie et al., 1990, 2001). With each subsequent ground-verification effort, the number of aerial survey polygons containing root disease has increased, while the number of polygons containing bear damage has decreased. Kanaskie et al. (1990) found that $24 \%$ of polygons contained root disease, and $76 \%$ contained black bear damage. Ten years later, $63 \%$ of polygons contained root disease and $42 \%$ contained black bear damage (Kanaskie et al., 2001). Our 2015 ground verification found that $92 \%$ of polygons contained root disease and $25 \%$ contained bear damage. More so, our observations showed that $85 \%$ of all red crowns were caused by root disease. This trend may be an indication that black bear damage management over the last 2 decades has reached a level of efficiency at reducing damage, and if continued, black bear damage may remain at low levels across the landscape. Conversely, the presence of root disease implies that stands may be unhealthy, and it has been shown that black bears damage the most productive, vigorously growing trees (Barnes and Engeman, 1995; Schmidt and Gourley, 1992). Thus, black bears may not damage trees in stands with high prevalence of root disease.

While our estimates of black bear damage were minimal, they were likely overestimates due to the way we simulated mortality of bearwounded trees in the growth models. In our Salvage and Total Loss scenarios, we removed the proportion of bear-wounded trees predicted to not survive at final harvest when, in reality, these wounded trees would die gradually over time. The mortality of wounded trees that would occur in each annual growth period would facilitate accelerated growth of adjacent undamaged trees, resulting in a response similar to that from repeated light thinning. Consequently, residual trees may result in greater volume outputs, compensating for the volume lost to mortality of black bear-wounded trees. Nevertheless, the majority of wounded trees were of low severity (89\%), thus, overestimates are likely minimal as the majority of wounded trees would have survived to harvest. It also is important to note that our models accounted for damage that occurred between stand initiation (i.e., time of planting) and 2015. Any additional damage that may occur between 2015 and harvest is unknown. Until black bear damaged stands are studied from planting to harvest, we will not truly understand the cumulative impacts of bear damage.

\section{Conclusions}

Realized economic impact of black bear damage to Douglas-fir varies with spatial scale, whether foresters leave or harvest damaged trees, and how damage is estimated. Our results suggest that aerial estimates of black bear damage do not detect trees that are damaged but not killed, while numbers of trees killed by black bears are 
overestimated due to the influence of multiple root diseases. Our methodology integrates several tools and techniques that are commonly used in forest valuation. Our findings suggest that previous estimates of bear peeling may overestimate economic loss by as much as 10 -fold at large scales. We submit that this approach should be further integrated into existing forest management plans where stands are vulnerable to peeling and black bear damage is likely. Managers may use results to guide silvicultural practices such as timing and intensity of thinning, fertilization, pruning, and harvesting (Kimball et al., 1998b, c).

\section{Acknowledgements}

We thank Doug Maguire for providing comments on this manuscript as well as guidance with forest growth and yield analyses. We thank Darius Adams for guidance with economic analyses; Ariel Muldoon for statistical support; Mike Rochelle, Tim McBride, Don Irons, and Jeff Light for site access, and Luke Kline for field assistance. Thanks to John Burnett, Evan and Angie Bredeweg, Lindsey Keener-Eck and Danielle Kloster for assistance with aerial imagery processing and identification. We thank Georg Ziegltrum, Alan Kanaskie, Rob Flowers and Mark Gourley for their continued support and interest in this study. Funds were provided by Oregon Forest Industries Council, Washington Forest Protection Association, and Oregon Department of Forestry.

\section{References}

Avery, T.E., Burkhart, H.E., 1983. Forest Measurements, third ed. McGraw Hill, New York.

Barnes, V.G., Engeman, R.M., 1995. Black bear damage to lodgepole pine in central Oregon. Northwest. Nat. 76, 127-129.

Black, H.C., Lawrence, W.H., 1992. Animal damage management in Pacific Northwest forests: 1901-90. In: Black, A., (Ed.), Silvicultural approaches to animal damage management in Pacific Northwest forests. USDA Forest Service Gen. Tech. Rep. PNWGTR-287. Portland, Oregon, pp. 32.

Cushman, S.A., McGarigal, K., 2003. Landscape-level patterns of avian diversity in the Oregon Coast Range. Ecol. Mono. 73, 259-281.

Dixon, G.E., 2002. Essential FVS: a guide to the forest vegetation simulator. USDA Forest Service, Internal Report, Forest Management Service Center, Colorado, pp. 246.

Dykstra, D., 2010. Batch processing in FRCS. USDA Forest Service Pacific Northwest Research Station, User guide for FRCS fact sheet, Oregon, pp. 10.

Engeman, R.M., 2002. Economic considerations of damage assessment. In: Clark, L., Hone, J., Shivik, J.A., Watkins, R.A., VerCauteren, K.C., Yoder, J.K. (Eds.), Human Conflicts with Wildlife: Economic Considerations. 3rd National Wildlife Research Center Special Symposium. USDA, Wildlife Services, National Wildlife Research Center, Fort Collins, Colorado 1-3 August 2000.

Fight, R.D., Hartsough, B.R., Noordijk, P., 2006. Users guide for FRCS: fuel reduction cost simulator software. USDA Forest Service, Gen. Tech. Rep. PNW-GTR-668, Oregon, pp. 30 .

Flowers, R.H., 1987. Supplemental feeding of black bear in tree-damaged areas of western Washington. In: Baumgartner, D.M., Mahoney, R.L., Evans, J., Caslick, J., Breuer, D.W. (Eds.), Proceedings of the Conference on Animal Damage Management in Pacific Northwest Forestry. Cooperative Extension. Washington State University Press, Pullman, WA.

Flowers, R.M., Norlander, D., Kanaskie, A., 2014. Memorandum: 2014 Aerial Survey of Tree Mortality in Northwest Oregon. Oregon Department of Forestry, Salem, OR, pp. 7 .

Freese, F., 1960. Testing accuracy. For. Sci. 6, 139-145.

Hartwell, H.D., Johnson, L.E., 1987. Silvicultural effects of basal girdling by black bear in a young Douglas-fir plantation. Washington State Department of Natural Resources Tech. Rep., pp. 31

Immell, D., Jackson, D.H., Boulay, M.C., 2013. Denning ecology of American black bears in the Cascade Mountains of Oregon. Ursus 24, 1-12.

Kanaskie, A., McWilliams, M., Overhulser, D., Christian, R., 2001. Black Bear Damage to Forest Trees in Northwest Oregon, Aerial and Ground Surveys 2000. Oregon Department of Forestry, Salem, OR, pp. 29.

Kanaskie, A., Irwin, G., Chetock, J., Overhulser, D., 1990. Black Bear Damage to Forest Trees in Northwest Oregon 1988-1989. Pest Management Report 90-1. Oregon Department of Forestry, Oregon,, pp. 37.

Kimball, B.A., Nolte, D.L., Engeman, R.M., Johnston, J.J., Stermitz, F.R., 1998a. Chemically mediated foraging preference of black bear (Ursus americanus). J. Mammalogy 79, 448-456.

Kimball, B.A., Turnblom, E.C., Nolte, D.L., Griffin, D.L., Engeman, R.M., 1998b. Effects of thinning and nitrogen fertilization on sugars and terpenes in Douglas-fir vascular tissues: implications for black bear foraging. For. Sci. 44, 599-602.

Kimball, B.A., Nolte, D.L., Griffin, D.L., Dutton, S.M., Ferguson, S., 1998c. Impacts of live canopy pruning on the chemical constituents of Douglas-fir vascular tissues: implications for black bear foraging. For. Ecol. Manage. 109, 51-56.

Kline, K.N., Taylor, J.D., Morzillo, A.T., 2018. Estimating stand-level economic impacts of black bear damage to intensively managed forests. Can. J. For. Res. 48, 758-765.

Lowell, E.C., Dykstra, D., McFadden, G., 2010. Effects of bear damage on Douglas-fir lumber recovery. W. J. of App. For. 25, 73-80.

Maguire, D.A., Mainwaring, D.B., Kanaskie, A., 2011. Ten year growth and mortality in young Douglas-fir stands experiencing a range in Swiss needle cast severity. Can. J. For. Res. 41, 2064-2076.

McDonald, P., Radosevich, S.R., 1992. General principles of forest vegetation management. In: Black, A (Ed.), Silvicultural approaches to animal damage management in Pacific Northwest forests. USDA Forest Service Gen. Tech. Rep. PNW-GTR-287. Portland, Oregon, pp. 19.

Nolte, D.L., Dykzeul, M., 2002. Wildlife impacts on forest resources. In: Clark, L., Hone, J., Shivik, J.A., Watkins, R.A., VerCauteren, K.C., Yoder, J.K. (Eds.), Human Conflicts with Wildlife: Economic Considerations. 3rd National Wildlife Research Center Special Symposium. USDA, Wildlife Services, National Wildlife Research Center, Fort Collins, Colorado 1-3 August 2000.

Oregon Department of Fish and Wildlife (ODFW), 2006. Oregon conservation strategy. Oregon Department of Fish and Wildlife, Oregon, pp. 12.

Oregon Forest Industries Council (OFRI), 2013. OFRI County Sheets. Oregon Forest Resources Institute, Portland, Oregon, pp. 36.

Pierson, D.J., 1966. Washington's black bear problem. Western Association of Game and Fish Commissioners 46, 96-100.

R Development Core Team, 2010. R: A language and environment for statistical computing. R Foundation for Statistical Computing, Vienna.

Radwan, M.A., 1969. Chemical composition of vascular tissue of four tree species in relation to feeding by black bear. For. Sci. 15, 11-16.

Schmidt, W., Gourley, M., 1992. Black bear. In: Black, H. (Ed.), Silvicultural approaches to animal damage management in Pacific Northwest forests. USDA Forest Service Gen. Tech. Rep. PNW-GTR-287, Oregon, pp. 3.

Taylor, J., Morzillo, A., Anderson, A., 2014. Estimating the total economic impact of black bear peeling in western Oregon using GIS and REMI. Vert. Pest Conf. 26, 419-422.

USDA Forest Service, 2014. What is FVS? US Forest Service Forest Management Service Center, Fort Collins, Colorado. Available from http://www.fs.fed.us/fmsc/fvs/ whatis/index.shtml (accessed January 2016).

Witmer, G., Nolte, D., Stewart, W., 2000. Integrated Pest Management of Black Bear Reforestation Damage. USDA National Wildlife Research Center-Staff Publications, pp. 228-235.

Ziegltrum, G.J., 2004. Efficacy of black bear supplemental feeding to reduce conifer damage in western Washington. J. Wildl. Manage. 68, 470-474.

Ziegltrum, G.J., 2006. Cost-effectiveness of the black bear supplemental feeding program in western Washington. Wildl. Soc. Bull. 34, 375-379. 